\title{
Empowering Women through Mangrove Batik Business in Percut Sei Tuan, North Sumatera
}

\author{
Ridahati Rambey $^{1 *}$, M. Zulham Efendi Sinaga ${ }^{2}$ \\ ${ }^{1}$ Faculty of Forestry, Universitas Sumatera Utara. Jl. Tri Dharma Ujung No. 1, Medan 20155, \\ North Sumatra, Indonesia \\ ${ }^{2}$ Department of Chemistry, Faculty of Mathematics and Natural Sciences, Universitas \\ Sumatera Utara, Medan, North Sumatra 20155, Indonesia \\ *Email: ridahatirambey@yahoo.com
}

\begin{abstract}
One of the efforts to improve community welfare is through community empowerment activities. Through the Community Service Program for women's groups in Percut Sei Tuan, it is hoped that women can increase family income. Available natural resources such as natural dyes made from wood around the mangrove forest can be used to support batik products with natural dyes. Types of natural dyes include those from the wood species Rhizopora, Avicennia, Ceriop, Bruguiera. In this service activity the group has made products in the form of handkerchiefs and printed batik cloths.
\end{abstract}

Keyword: Mangrove, Batik

\begin{abstract}
Abstrak
Salah satu upaya untuk meningkatkan kesejahteraan masyarakat adalah melalui kegiatan pemberdayaan masyarakat. Melalui Program Pengabdian Masyarakat pada kelompok perempuan di Percut Sei Tuan diharapkan perempuan dapat meningkatkan pendapatan keluarga. Sumber daya alam yang tersedia seperti pewarna alam yang terbuat dari kayu di sekitar hutan mangrove dapat dimanfaatkan untuk menunjang produk batik dengan pewarna alam. Jenis pewarna alami termasuk yang berasal dari spesies kayu Rhizopora, Avicennia, Ceriop, Bruguiera. Dalam kegiatan bakti ini rombongan telah membuat produk berupa sapu tangan dan kain batik cap..
\end{abstract}

Keyword: Mangrove, Batik

\section{INTRODUCTION}

angrove forests have ecological benefits as a deterrent to abrasion and are able to improve environmental quality, which is marked by increasing biodiversity. Apart from their ecological function, mangroves also have economic benefits. One of the benefits of mangroves is for the batik coloring process using plant-based ingredients (Dewi, 2016).

Dyes can be divided into 2, namely synthetic dyes and natural dyes. Synthetic dyes are very practical to use and can bring out a striking color to the dyed product. This makes synthetic dyes often used in the food and beverage, pharmaceutical and textile industries. However, the waste or residue from synthetic dyes can pollute the environment if not treated optimally

Natural dyes are dyes obtained from nature or plants, either directly or indirectly. Traditionally natural dyes are obtained by extracting or boiling plants. Plant parts that can be used for natural dyes include bark, twigs, leaves, roots, flowers, and seeds. In mangrove fruit contains a lot of tannins which are natural brown dyes. Tannins can be used for batik dyes (Paryanto, 2016) 
The Women's Group, which is the object of community service activities, is located on the East Coast of North Sumatra, precisely in Tanjung Rejo Village, Percut Sei Tuan District, Deli Serdang Regency, North Sumatra Province.

\section{METHODS}

\section{Making dyes from mangrove materials}

a. Prepare the coloring ingredients, namely the fruit and skins of Rhizopora and Bruguiera

b. One kilogram of Bruiguiera fruit or skin is added with 6 liters of water or equal to 1: 6 , then heated until it shrinks to $2 / 3$ parts then cooled.

c. The dye is ready to use

\section{Making of Batik}

a. Preparation of tools and materials for making Written Batik. Mori cloth, Canting, Gawangan and candles, pot and stove and dye solution

b. Making written batik patterns. The way to make it is a batik design by painting the desired picture on the fabric.

c. Painting with heated wax using canting following the pattern that has been designed

d. Dyeing the fabric color in a certain color so that the non-waxed fabric can be dyed, then dried and dried

e. After drying, do the painting process with wax again and then do the second color immersion in the mangrove dye

f. Remove wax from fabrics by placing a cloth with hot water on the stove

g. After that, batik is done by closing the candle to hold the first and second colors

h. The cloth is boiled in hot water to remove the wax coating so that the motif can be seen clearly

i. Washed batik cloth and dried afterwards before use

\section{Making of Batik Stamp}

a. The Mori cloth is placed on a table that has been covered with a soft base.

b. Boiled by wax until melted and maintained so that the temperature of the night liquid remains in a state of 60 to 70 degrees Celsius

c. The cap is then put into the wax liquid by dipping approximately $2 \mathrm{~cm}$ dipped in the wax liquid at the bottom of the cap

d. The stamp is then placed and pressed with sufficient force on the cloth that has been prepared earlier, the wax is allowed to seep into the pores of the cloth until it penetrates the other side of the cloth.

e. After the stamp process is complete, the mori cloth will then enter the coloring process by dipping the mmori cloth into the vat containing the mangrove dye.

f. The hot wax has penetrated the surface of the fabric, it will not penetrate the surface of the cloth, it will not be exposed in this coloring process.

g. The hot wax liquid has soaked onto the surface of the fabric, it will not be affected in this coloring process. After the coloring process is complete, it is continued with the next process, namely removing the traces of the wax fluid through the boiling or ngelorot process so that two colors will appear, namely the original basic color of the mori cloth.

$\mathrm{h}$. The final process of cleaning and color lightening with soda is after drying and ironing

\section{RESULT AND DISCUSSION)}

\section{Preparation of Natural Dyes}


The natural dyes used are natural dyes from mangrove bark and stems. The bark and trunk can be taken from dead or living wood. For living logs, only one third of the bark is extracted so that the tree remains alive and wounds on the wood quickly recover to normal. The wound on the wood will naturally close again if done properly. Taking natural dyes from dead or rotting wood on the edge of the sea is recommended so that the mangrove ecosystem can be preserved.

Types of wood that can be used include flourish (Sonneratia caseolaris), Rhizopora apiculata, Rhizopora mucronata, Rhizopora stylosa, Avicennia marina, Bruiguiera gymnrhiza, Bruguirea parvifolia, Avicennia marina, Avicennia alba, Tengar (Ceriops tagal). Each type of tree will produce a different color. The type of dye that we will use as desired. To be able to produce a stronger color, usually the bark taken is the bark from the lower area of the tree near the roots to the first branch on the tree. If the uyang branch is above the resulting color is less strong or less bright. The following is the process of taking mangrove bark.
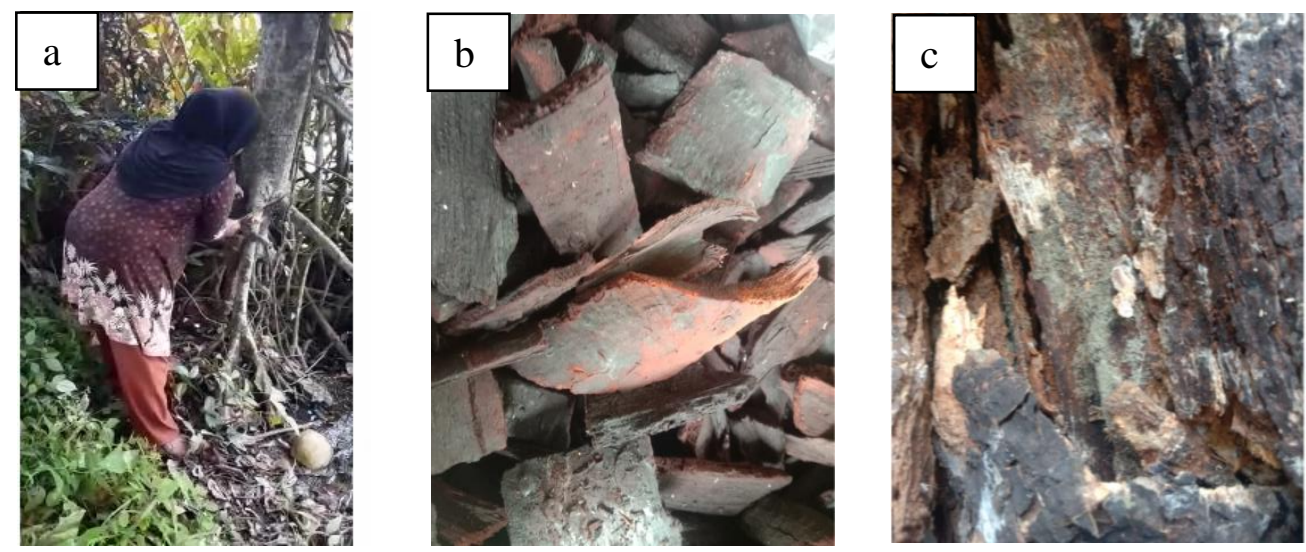

Figure 1. (a) The process of extracting mangrove bark, (b) Ceriops tagal bark, (c) Evolving bark (Sonneratia alba)

\section{Making of Written Batik Patterns}

Pattern making on written batik is done by drawing the cloth first according to the desired motif. What is needed for drawing is an ordinary pencil. In basic training, written batik is made on a handkerchief size. Motifs made according to the wishes of group members are pictures of leaves, flowers, sea horses, dolls, and pictures of abstark. It takes a long time to make written batik on 2 meter shirt pattern because of the wide size of the cloth.

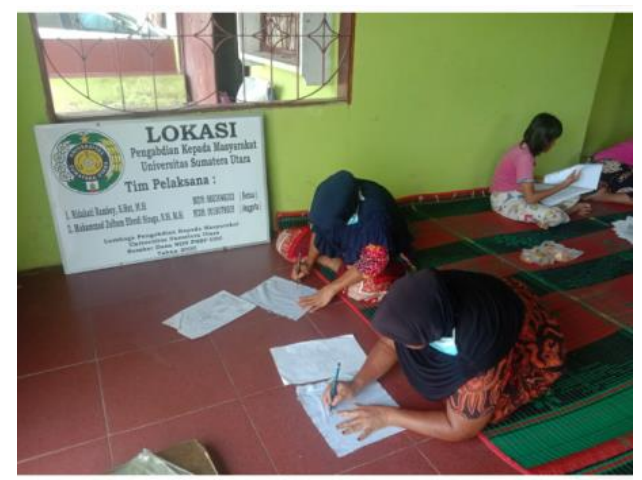

Figure 2. Making a written batik pattern 


\section{Deployment}

Preparation before chanting is to preheat the wax at a temperature of 60 to 70 degrees Celsius on the canting stove. After the wax has melted, it is craved for a while, and in warm conditions, it is pressed. Cutting is done carefully so that it looks neat in accordance with the previously made pattern. Pengantingan aims to draw a pattern on the cloth. The embroidery process on written batik takes a long time. The wider the fabric to be painted, the longer the working process will be.
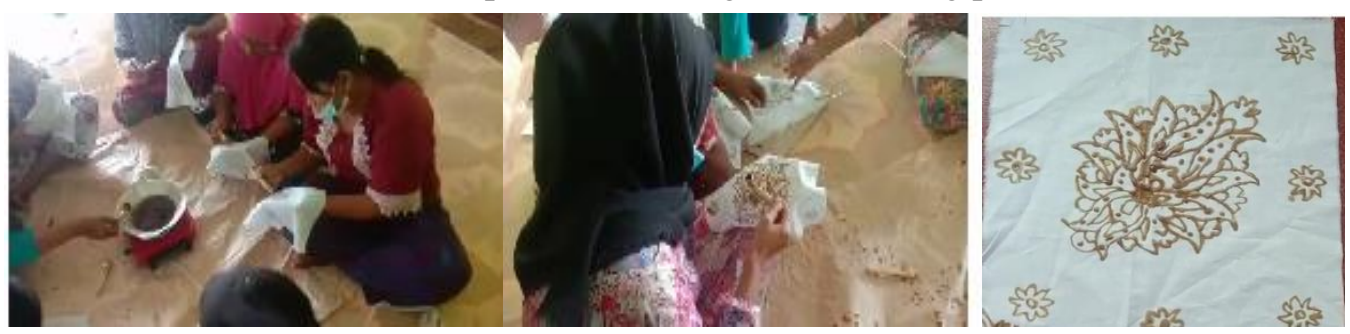

Figure 3. Canting proces

\section{Making of Batik}

Stamped batik is made with the help of a stamp. The method of manufacture is to prepare a cloth 2 meters wide. Then the cloth is placed on the table which has been covered with foam. The 2 meter width of the table is the same as the size of the cloth, this is to make the stamp evenly on the fabric. Candles are boiled.
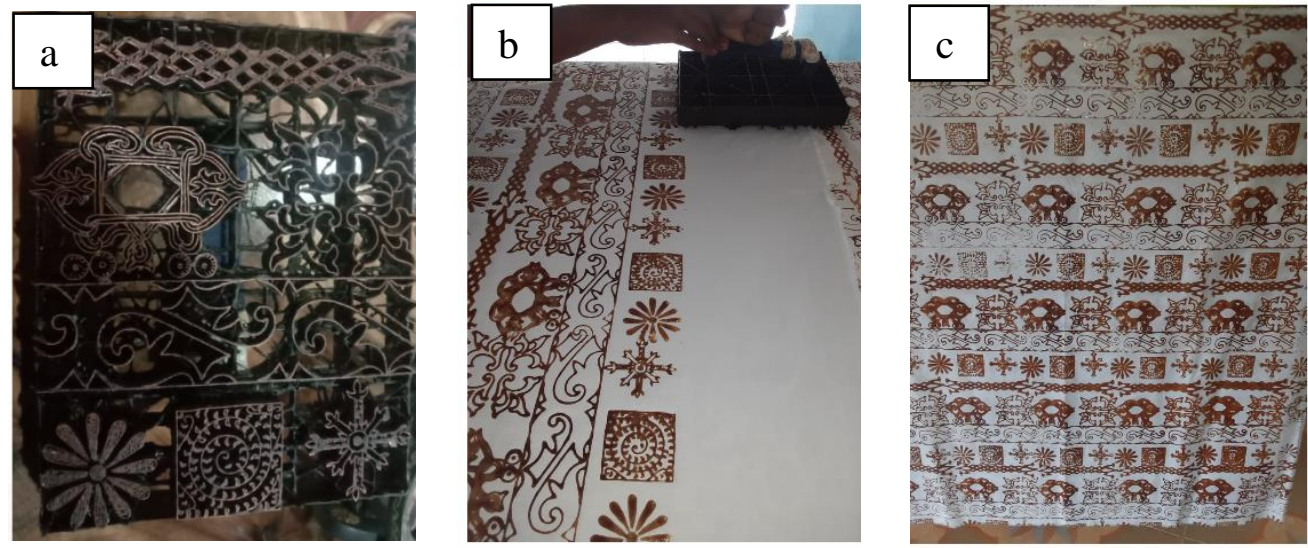

Figure 4. (a) Stamp tool, (b) The process of making a stamp, (c) Cloth that has been stamped

\section{Washing with Tro}

Washing with tro aims to open the fibers of the fabric, so that the dyeing process with natural dyes can be maximally characterized by natural dyes that can be absorbed by the fabric.

\section{Color making}

The bark that has been taken from the field is boiled for one hour at a temperature of 80 degrees Celsius. The composition of the mangrove bark used is 1 kilogram mixed with 5 buckets of water and cooked for 1 hour, after which it is left to stand for one day. In this handkerchief coloring practice, two types of bark are used, namely the swollen skin and the tengar skin.

\section{Process of coloring}

In the process of coloring written batik and printed batik, the process is basically the same. Canting or stamped fabrics are dipped in natural dyes that have been prepared in advance. After dipping it in the sun without being squeezed. This continues until the immersion process in natural dyes is repeated 4 times. Repetition is done so that the color of the natural dye is straightforward and the color is good. 


\section{Fixation (Color strengthening)}

In the fixation process, the materials used are lime, alum and gazebo. The trick is that all the ingredients are dissolved in cold water and then dissolved evenly after that the cloth is dipped in the water without being squeezed and dried in the sun to dry.

\section{Pelorotan (the process of removing wax from the cloth)}

Pelorotan is done to remove wax from the cloth. Pelorotan is done by boiling water with the ingredient "Soda As" after the mori cloth is boiled in water with a solution of boiling tunjung, the wax will come off after it is immersed in cold water, squeezed and then dried and then ironed.

\section{CONCLUSION}

Types of wood that can be used as natural dyes include flour (Sonneratia caseolaris), Rhizopora apiculata, Rhizopora mucronata, Rhizopora stylosa, Avicennia marina, Bruiguiera gymnrhiza, Bruguirea parvifolia, Avicennia marina, Avicennia alba, Tengar (Ceriops tagal). Natural dyes can be used from living or dead wood. Utilization of natural dyes from dead wood is preferable to be able to preserve the environment. The process of making batik with natural dyes takes longer than chemical dyes. The process of making printed batik is faster than making batik by using canting

\section{ACKNOWLEDGMENTS}

This community service activities was supported by LPPM USU grant of Universitas Sumatera Utara No.287/UN5.2.3.2.1/PPM/2020 (Regular mono year program). Our sincerely thank also goes to Community Tanjung Rejo Village.

\section{REFERENCES}

Potential Data for Tanjung Rejo Village, 2003.

Dewi NK, Kariada N, Febriana F. 2016. Green Economic Concept by Providing Batik Natural Color from Mangrove Plants. Engineering Journal Vol. 14. No 2 (2016)

Pringgenies D, Supriyantini E, Azizah R, Hartati, Iewani, Radjasa K. 2013. Application of Natural Mangrove Coloring for Batik Materials as Business Diversification in the Assisted Village, Semarang Regency. Info Magazine, Number 1, February. ISSN: 0852 - 1816 XV Edition.

Paryanto, Wibowo WA, Aditya MH, 2016. Making Natural Dyes from Mangrove Fruits Rhizopora stylosa as Environmentally Friendly Batik Dyes on a Plot Scale. Proceedings of the National Seminar on Waste Management Technology XIV Center for Radioactive Waste Technology - BATAN ISSN 1410 - 6086

Nur Kusuma Dewi, Nana Kariada TM, Fidia Febriana, 2016. Green Economic Concept by Providing Natural Batik Dyes from Mangrove Plants. Engineering Journal Vol. 14 No. 2, December 2016.

Wirawan B D S, Siddiqi, HA. 2017. Natural Color Exploration Using Bark, Roots, Duan and Fruit of Mangrove Plants (Rhizopora stylosa) As Batik Dyes Using Alum, Tunjung and Lime Fixators. Pekalongan City Research and Development Journal Vol. 13 of 2017. 